\title{
Tris(pyrone) Chelates of Gd(III) as High
}

\section{Solubility, High Relaxivity MRI-CA}

David T. Puerta, Mauro Botta, * Christoph J. Jocher, Eric J. Werner, Stefano Avedano, Kenneth N. Raymond, and Seth M. Cohen *

Dept. of Chemistry and Biochemistry, University of California, San Diego La Jolla, CA 92093

Dept. of Chemistry, University of California, Berkeley, Berkeley, CA 94720, and Dept. of Environmental and Life Sciences, University of Eastern Piedmont “A. Avogadro", Via Bellini 25/G, 15100 Alessandria, Italy

\section{Supporting Information}

*Author to whom correspondence should be addressed. Telephone: (858) 822-5596. FAX: (858) 822-5598. E-mail: scohen@ucsd.edu. 
General. Unless otherwise noted, starting materials were obtained from commercial suppliers and used without further purification. Elemental analysis was performed at NuMega Resonance Labs, San Diego, California. ${ }^{1} \mathrm{H} /{ }^{13} \mathrm{C}$ NMR spectra were recorded on a Varian FT-NMR spectrometer running at 300 or $400 \mathrm{MHz}$ at the Department of Chemistry and Biochemistry, University of California, San Diego. Mass spectra were acquired at the Small Molecule Mass Spectrometry Facility located in the Department of Chemistry and Biochemistry, University of California, San Diego. Compound 2 (2formyl-3-benzyloxy-pyran-4(1H)-one, Scheme 1) was synthesized from maltol (3hydroxy-2-methyl-4-pyrone) according to a literature procedure (Pace P.; Nizi E.; Pacini, B.; Pesci, S.; Matassa, V.; De Francesco, R.; Altamura, S.; Summa, V. Bioorg. Med. Chem. Lett. 2004, 14, 3257). Compound 3 (2-carboxy-3-benzyloxy-pyran-4(1H)-one) was synthesized using an analogous procedure for the synthesis of 2-carboxy-3benzyloxy-6-methyl-pyran-4(1H)-one as described by a literature procedure (Liu, Z.D.; Piyamongkol, S.; Liu, D.Y; Khodr, H.H.; Lu, S.L.; Hider, R.C. Bioorg. Med. Chem. 2001, 9, 563).

Protected-TRENMAM (5). To a suspension of 3 (3.0 g, $12.2 \mathrm{mmol})$ in dry THF (90 $\mathrm{mL})$ was added NHS (1.4 g, $12.2 \mathrm{mmol})$ and the mixture was stirred at room temperature under $\mathrm{N}_{2}(\mathrm{~g})$ for $30 \mathrm{~min}$. DCC (2.52 $\left.\mathrm{g}, 12.2 \mathrm{mmol}\right)$ was then added and the mixture was stirred at room temperature under $\mathrm{N}_{2}(\mathrm{~g})$ for $3 \mathrm{~h}$. The DCU precipitate was removed by filtration, and to the resulting filtrate was added a solution of tris(2-aminoethyl)amine (TREN, $607.5 \mu \mathrm{L}, 4.1 \mathrm{mmol})$ in THF $(10 \mathrm{~mL})$ dropwise over $15 \mathrm{~min}$. The reaction mixture was stirred overnight at room temperature under $\mathrm{N}_{2}(\mathrm{~g})$. A white precipitate was 
filtered off and the filtrate was evaporated to dryness to obtain an amber oil. The oil was dissolved in $\mathrm{CHCl}_{3}$. The $\mathrm{CHCl}_{3}$ solution was washed with $2 \times 150 \mathrm{~mL}$ of saturated $\mathrm{NaHCO}_{3}$. The organic layer was dried over $\mathrm{MgSO}_{4}$ and filtered. The filtrate was evaporated to obtain an amber oil. The oil was purified by silica column chromatography $\left(\mathrm{CHCl}_{3}\right.$ with $\left.0-9 \% \mathrm{MeOH}\right)$ to yield a foamy off-white solid $(2.7 \mathrm{~g}, 80 \%) . \quad{ }^{1} \mathrm{H}$ NMR $\left(\mathrm{CDCl}_{3}, 300 \mathrm{MHz}, 25^{\circ} \mathrm{C}\right): \delta 2.30\left(\mathrm{t}, J=6.4 \mathrm{~Hz}, 6 \mathrm{H}, \mathrm{CH}_{2}\right), 3.12(\mathrm{q}, J=6.0 \mathrm{~Hz}, 6 \mathrm{H}$, $\left.\mathrm{CH}_{2}\right), 5.33$ (s, 6H, benzyl- $\left.\mathrm{CH}_{2}\right), 6.46(\mathrm{~d}, J=6.0 \mathrm{~Hz}, 3 \mathrm{H}$, pyrone-H), 7.34 (s, $15 \mathrm{H}$, benzylH), 7.69 (t, $J=5.4 \mathrm{~Hz}, 3 \mathrm{H}$, amide-H), $7.82\left(\mathrm{~d}, J=5.4 \mathrm{~Hz}, 3 \mathrm{H}\right.$, pyrone-H). ${ }^{13} \mathrm{C}$ NMR $\left(\mathrm{CDCl}_{3}, 100 \mathrm{MHz}, 25^{\circ} \mathrm{C}\right): \quad \delta 25.5,36.6,52.4,75.3,117.4,128.7,129.0,135.2,146.8$, 154.6, 159.4, 172.3, 175.6. ESI-MS(+): $m / z 853.18[\mathrm{M}+\mathrm{Na}]^{+}$.

TRENMAM. To $5(500 \mathrm{mg}, 0.6 \mathrm{mmol})$ was added $13.5 \mathrm{~mL}$ of a $1: 1$ solution of concentrated $\mathrm{HCl}$ and glacial acetic acid. The suspension was stirred under $\mathrm{N}_{2}(\mathrm{~g})$ for 24 $\mathrm{h}$ at room temperature. The reaction was co-evaporated with methanol $(3 \times 20 \mathrm{~mL})$ and dried under vacuum to yield a white solid (280 mg, 83\%). ${ }^{1} \mathrm{H}$ NMR ( $d$-DMSO, 400 $\mathrm{MHz}, 25^{\circ} \mathrm{C}$ ): $\delta 3.40\left(\right.$ br t, $\left.6 \mathrm{H}, \mathrm{CH}_{2}\right), 3.69\left(\right.$ br q, $\left.6 \mathrm{H}, \mathrm{CH}_{2}\right), 6.46(\mathrm{~d}, J=5.2 \mathrm{~Hz}, 3 \mathrm{H}$, pyrone-H), 8.15 (d, $J=5.6 \mathrm{~Hz}, 3 \mathrm{H}$, pyrone-H), 8.92 (t br, 3H, amide-H), 10.25 (s br, $1 \mathrm{H}$, $\mathrm{OH}), 11.20$ (s br, $2 \mathrm{H}, \mathrm{OH}) .{ }^{13} \mathrm{C}$ NMR $\left(d\right.$-DMSO, $\left.100 \mathrm{MHz}, 25^{\circ} \mathrm{C}\right): \delta 51.1,114.5,136.7$, 148.1, 154.8, 162.4, 173.2. $\quad$ ESI-MS(+): $m / z 561.10[\mathrm{M}+\mathrm{H}]^{+}$. Anal. Calcd for $\mathrm{C}_{24} \mathrm{H}_{24} \mathrm{~N}_{4} \mathrm{O}_{12} \cdot 2.5 \mathrm{H}_{2} \mathrm{O}:$ C, 47.61; H, 4.83; N, 9.25. Found: C, 47.85; H, 4.83; N, 8.81.

Protected-TREN-Me-MAM. Protected-TREN-Me-MAM was synthesized in a similar manner to the preparation of 5 , but starting from $2.0 \mathrm{~g}(7.6 \mathrm{mmol})$ of 2-carboxy-3- 
benzyloxy-6-methyl-pyran-4(1H)-one (Puerta, D.T.; Mongan, J.; McCammon, J.A.; Cohen, S.M. J. Am. Chem. Soc. 2005, 127, 14148). The product was isolated as a white foamy solid $(2.0 \mathrm{~g}, 90 \%) .{ }^{1} \mathrm{H} \mathrm{NMR}\left(\mathrm{CDCl}_{3}, 300 \mathrm{MHz}, 25^{\circ} \mathrm{C}\right): \delta 2.30(\mathrm{t}, J=6.6 \mathrm{~Hz}$, 6H, $\mathrm{CH}_{2}$ ), 2.36 (s, 9H, methyl-H), 3.10 (q, $J=6.0 \mathrm{~Hz}, 6 \mathrm{H}, \mathrm{CH}_{2}$ ), 5.33 (s, 6H, benzyl$\left.\mathrm{CH}_{2}\right), 6.26(\mathrm{~s}, 3 \mathrm{H}$, pyrone-H), $7.31(\mathrm{~s}, 15 \mathrm{H}$, benzyl-H), $7.70(\mathrm{t}, J=5.4 \mathrm{~Hz}, 3 \mathrm{H}$, amideH). ${ }^{13} \mathrm{C} \mathrm{NMR}\left(\mathrm{CDCl}_{3}, 100 \mathrm{MHz}, 25{ }^{\circ} \mathrm{C}\right): \quad \delta 25.5,36.8,52.3,75.3,79.1,117.4,128.7$, 129.1, 135.2, 146.8, 154.6, 159.0, 172.3, 175.7. ESI-MS(+): $m / z 895.20[\mathrm{M}+\mathrm{Na}]^{+}$.

TREN-Me-MAM. Protected-TREN-Me-MAM (1.8 g, $2.1 \mathrm{mmol})$ was dissolved in methanol $(100 \mathrm{~mL})$. To this solution was added $110 \mathrm{mg} 10 \% \mathrm{Pd} / \mathrm{C}$ and the mixture was placed under $\mathrm{H}_{2}(\mathrm{~g})$ at $35 \mathrm{psi}$ for $16 \mathrm{~h}$. The Pd catalyst was removed by filtration and the filtrate was evaporated to a white solid (1.1 g, 89\%). ${ }^{1} \mathrm{H}$ NMR ( $d$-DMSO, $400 \mathrm{MHz}, 25$ $\left.{ }^{\circ} \mathrm{C}\right): \delta 2.25$ (s, 9H, methyl-H), $2.71\left(\mathrm{br} \mathrm{t}, 6 \mathrm{H}, \mathrm{CH}_{2}\right), 3.35$ (br q, $\left.6 \mathrm{H}, \mathrm{CH}_{2}\right), 6.24(\mathrm{~d}, J=5.2$ $\mathrm{Hz}, 3 \mathrm{H}$, pyrone-H), 8.61 (t br, $3 \mathrm{H}$, amide-H). ${ }^{13} \mathrm{C}$ NMR ( $d$-DMSO, $\left.100 \mathrm{MHz}, 25{ }^{\circ} \mathrm{C}\right): \delta$ 19.4, 37.3, 52.5, 112.4, 136.0, 147.1, 162.1, 164.4, 173.3. IR (KBr pellet): $v 1233,1352$, 1443, 1553, 1653, $3411 \mathrm{~cm}^{-1}$. ESI-MS(+): $m / z 625.14[\mathrm{M}+\mathrm{Na}]^{+}$. Anal. Calcd for $\mathrm{C}_{27} \mathrm{H}_{30} \mathrm{~N}_{4} \mathrm{O}_{12} \bullet 2 \mathrm{H}_{2} \mathrm{O}:$ C, 50.78; H, 5.37; N, 8.77. Found: C, 50.48; H, 5.53; N, 8.72.

[Gd(TRENMAM)]. TRENMAM (150 $\mathrm{mg}, 0.27 \mathrm{mmol})$ was dissolved in hot methanol $(100 \mathrm{~mL})$ and water $(50 \mathrm{~mL}) . \mathrm{Gd}\left(\mathrm{NO}_{3}\right)_{3} \cdot 5 \mathrm{H}_{2} \mathrm{O}(110 \mathrm{mg}, 0.25 \mathrm{mmol})$ was added to the hot solution, followed by an excess of pyridine. The reaction mixture was heated to reflux for $2 \mathrm{~h}$. The reaction mixture was evaporated to dryness giving an off-white 
solid. The solid was washed with a minimal amount of methanol and dried to yield an off-white solid (180 mg, 94\%). ESI-MS(+): $m / z 716.03[\mathrm{M}+\mathrm{H}]^{+}$.

[Gd(TREN-Me-MAM)]. TREN-Me-MAM (100 mg, $0.17 \mathrm{mmol}$ ) was dissolved in ethanol $(15 \mathrm{~mL})$, and $\mathrm{Gd}\left(\mathrm{NO}_{3}\right)_{3} \cdot 5 \mathrm{H}_{2} \mathrm{O}(72 \mathrm{mg}, 0.17 \mathrm{mmol})$ was added to the solution, which instantly precipitated a white solid. To this suspension was added an excess of pyridine. The reaction mixture was heated to reflux for $2 \mathrm{~h}$, followed by hot filtration of the solid. The white solid was washed with a minimal amount of cold ethanol and dried (90 mg, 72\%). IR (KBr pellet): $v 1250,1384,1454,1552,1602,3419 \mathrm{~cm}^{-1}$. ESI-MS(+): $m / z 780.07[\mathrm{M}+\mathrm{Na}]^{+}$.

[Fe(TREN-Me-MAM)]. TREN-Me-MAM (100 mg, $0.17 \mathrm{mmol})$ was dissolved in methanol $(20 \mathrm{~mL})$, and $\mathrm{FeCl}_{3} \cdot 6 \mathrm{H}_{2} \mathrm{O}(45 \mathrm{mg}, 0.17 \mathrm{mmol})$ was added, followed by the addition of an excess of pyridine. The resulting red suspension was heated at reflux for 2 h. The reaction mixture was evaporated to dryness and sonicated in isopropanol, filtered, and dried. The complex was further purified by silica column chromatography $\left(\mathrm{CHCl}_{3}\right.$ with $3 \% \mathrm{MeOH})$ to yield a red solid $(95 \mathrm{mg}, 87 \%)$. ESI-MS(+): $m / z 678.11[\mathrm{M}+\mathrm{Na}]^{+}$.

X-Ray Crystallographic Analysis. Red cubes of [Fe(TREN-Me-MAM)] suitable for X-ray diffraction structural determination were grown by slow evaporation from chloroform. Data were collected on a Bruker AXS area detector diffractometer. Crystals were mounted on quartz capillaries by using Paratone oil and were cooled in a nitrogen stream (Kryo-flex controlled) on the diffractometer $\left(-173{ }^{\circ} \mathrm{C}\right)$. Peak integrations were 
performed with the Siemens SAINT software package. Absorption corrections were applied using the program SADABS. Space group determinations were performed by the program XPREP. The structures were solved by direct methods and refined with the SHELXTL software package (Sheldrick, G.M. SHELXTL vers. 5.1 Software Reference Manual; Bruker AXS: Madison, WI, 1997). All hydrogen atoms were fixed at calculated positions with isotropic thermal parameters; all non-hydrogen atoms were refined anisotropically. CCDC deposition number 289563.

Solution Thermodynamics. The experimental protocols and equipment used have been previously described (Johnson, A. R.; O'Sullivan, B.; Raymond, K. N. Inorg. Chem. 2000, 39, 2652). To determine the protonation constants of the free ligands, approximately $15 \mathrm{mg}$ of ligand was dissolved in $50 \mathrm{~mL}$ of a $1.0 \mathrm{M}$ aqueous solution of $\mathrm{NaCl}$ in a titration vessel (ligand concentration $\sim 0.5 \mathrm{mM}$ ). Protonation constants of TRENMAM and TREN-Me-MAM were examined by potentiometric ( $\mathrm{pH}$ vs total proton concentration) titrations by using Hyperquad (Gans, P.; Sabatini, A.; Vacca, A. Talanta 1996, 43, 1739) for data analysis. Each protonation constant determination is the result from at least three experiments (where each experiment consists of two titrations, the first one titrated with acid, followed by a reverse titration with base). The equilibration time between additions of titrant was 90 seconds.

To determine the formation constants of [Gd(TRENMAM)], the same solutions and equipment were used as in the determination of the protonation constants of the free ligands. Approximately $12 \mathrm{mg}$ of TRENMAM was dissolved in $50 \mathrm{~mL}$ of a $1.0 \mathrm{M}$ aqueous solution of $\mathrm{NaCl}$, followed by the addition of an equimolar amount of aqueous 
$\mathrm{GdCl}_{3}$ solution (TRENMAM and $\mathrm{Gd}$ concentration $\sim 0.4 \mathrm{mM}$ ). The solution was acidified to a $\mathrm{pH}$ of 2.5 with $0.1 \mathrm{M} \mathrm{HCl}$ and the resulting solution was then titrated with $0.1 \mathrm{M} \mathrm{NaOH}$ in $0.05 \mathrm{~mL}$ increments to a final $\mathrm{pH}$ of 11 . The [ $\mathrm{Gd}(\mathrm{TRENMAM})\left(\mathrm{H}_{2} \mathrm{O}\right)_{2}$ ] complex did not fully disassociate under these conditions, therefore a titration at lower $\mathrm{pH}(1.6-2.5)$ was also performed. For these measurements, a correction of the liquidliquid junction potential for low $\mathrm{pH}$ was performed in the course of $\mathrm{pH}$ electrode calibration as in former work (Johnson, A. R.; O'Sullivan, B.; Raymond, K. N. Inorg. Chem. 2000, 39, 2652).

The titrations at a lower $\mathrm{pH}$ still failed to fully disassociate the complex due to the acidic nature of the ligand (Figure S2). Therefore, a $\beta_{110}$ could not be determined and was calculated from a competition titration with DTPA (vide infra). The other formation constants, $\beta_{111}$ and $\beta_{112}$, were determined from experiments (where each experiment consists of two titrations, the first one titrated with acid, followed by a reverse titration with base). The refinement of two experiments between $\mathrm{pH}=2.5-10.5$ and six titrations at low $\mathrm{pH}$ from $\mathrm{pH}=1.6-2.5$, using a junction potential calibration (as described in Johnson, A.R.; O'Sullivan, B.; Raymond, K.N. Inorg. Chem. 2000, 39, 2652) with fixed ligand protonation constants and a fixed $\beta_{110}$ gave $\beta_{111}=22.15(9)$ and $\beta_{112}=25.2(2)$ for [Gd(TRENMAM)]. The equilibration time between additions of titrant was 300 seconds.

Competition Titration with DTPA. The general procedure used to determine the pGd of $[\mathrm{Gd}(\mathrm{TRENMAM})]$ and $[\mathrm{Gd}(\mathrm{TREN}-\mathrm{Me}-\mathrm{MAM})]$ by competition batch titration was adapted from a previous report (Doble, D.M.J.; Melchior, M.; O'Sullivan, B.; Siering, C.; Xu, J.; Pierre, V.C.; Raymond, K.N. Inorg. Chem. 2003, 42, 4930). Varying volumes of 
a standardized DTPA stock solution were added to solutions containing constant ligand, metal, and electrolyte concentrations. The $\mathrm{pH}$ of all solutions was adjusted to 7.4 with $\mathrm{HCl}$ and/or $\mathrm{KOH}$ and the solutions were diluted to identical volumes. The concentrations of TRENMAM or TREN-Me-MAM relative to DTPA used in the final data analysis ranged from 1:0.1 to 1:10 (TRENMAM:DTPA or TREN-Me-MAM:DTPA). After stirring for $24 \mathrm{~h}$ to ensure thermodynamic equilibrium, concentrations of free and complexed TRENMAM or TREN-Me-MAM were determined from the absorption spectra, using the wavelength range of $335-370 \mathrm{~nm}$ and the spectra of free and fully complexed TRENMAM or TREN-Me-MAM at identical $\mathrm{pH}$ and concentrations as references for the analysis. Three titrations were performed, resulting in a pGd of 19.27 \pm 0.08 and $19.03 \pm 0.04$ for TRENMAM (Figure S3) and TREN-Me-MAM, respectively.

\section{Complete Reference Number 15:}

Mato-Iglesias, M.; Platas-Iglesias, C.; Djanashvili, K.; Peters, J. A.; Toth, V.; Balogh, E.; Muller, R. N.; Elst, L. V.; de Blas, A.; Rodriguez-Blas, T., The highest water exchange rate ever measured for a $\mathrm{Gd}(\mathrm{III})$ chelate. Chem. Commun. 2005, 4729-4731. 
Table S1. Summary of X-ray structural parameters for [Fe(TREN-Me-MAM)].

\begin{tabular}{|c|c|}
\hline & [Fe(TREN-Me-MAM)] \\
\hline Emp. Formula & $\mathrm{C}_{27} \mathrm{H}_{27} \mathrm{~N}_{4} \mathrm{O}_{12} \mathrm{Fe}$ \\
\hline Crystal System & Cubic \\
\hline Space Group & $P 2_{1} / c$ \\
\hline $\begin{array}{ll}\begin{array}{l}\text { Unit } \\
\text { dimensions }\end{array} & \text { Cell } \\
\end{array}$ & $a=b=c=17.6481(5) \AA$ \\
\hline Volume, $Z$ & $5496.6(3) \AA^{3}, 8$ \\
\hline Crystal size & $0.20 \times 0.20 \times 0.20 \mathrm{~mm}^{3}$ \\
\hline Temperature $(\mathrm{K})$ & $100(2)$ \\
\hline $\begin{array}{l}\text { Reflections } \\
\text { collected }\end{array}$ & 48183 \\
\hline $\begin{array}{l}\text { Independent } \\
\text { reflections }\end{array}$ & $4236[R($ int $)=0.0669]$ \\
\hline Data/rest./para. & $4236 / 0 / 267$ \\
\hline $\begin{array}{l}\text { Goodness-of-fit } \\
\text { on } \mathrm{F}^{2}\end{array}$ & 1.057 \\
\hline $\begin{array}{lll}\text { Final } & R & \text { indices } \\
\mathrm{I}>2 \sigma(\mathrm{I}) & a\end{array}$ & $\begin{array}{l}R 1=0.0556 \\
w R 2=0.1313\end{array}$ \\
\hline $\begin{array}{l}R \text { indices (all } \\
\text { data) }\end{array}$ & $\begin{array}{l}R 1=0.0715 \\
w R 2=0.1397\end{array}$ \\
\hline $\begin{array}{l}\text { Largest peak/hole } \\
\text { difference }\end{array}$ & $0.837 /-0.437$ e $\AA^{-3}$ \\
\hline
\end{tabular}




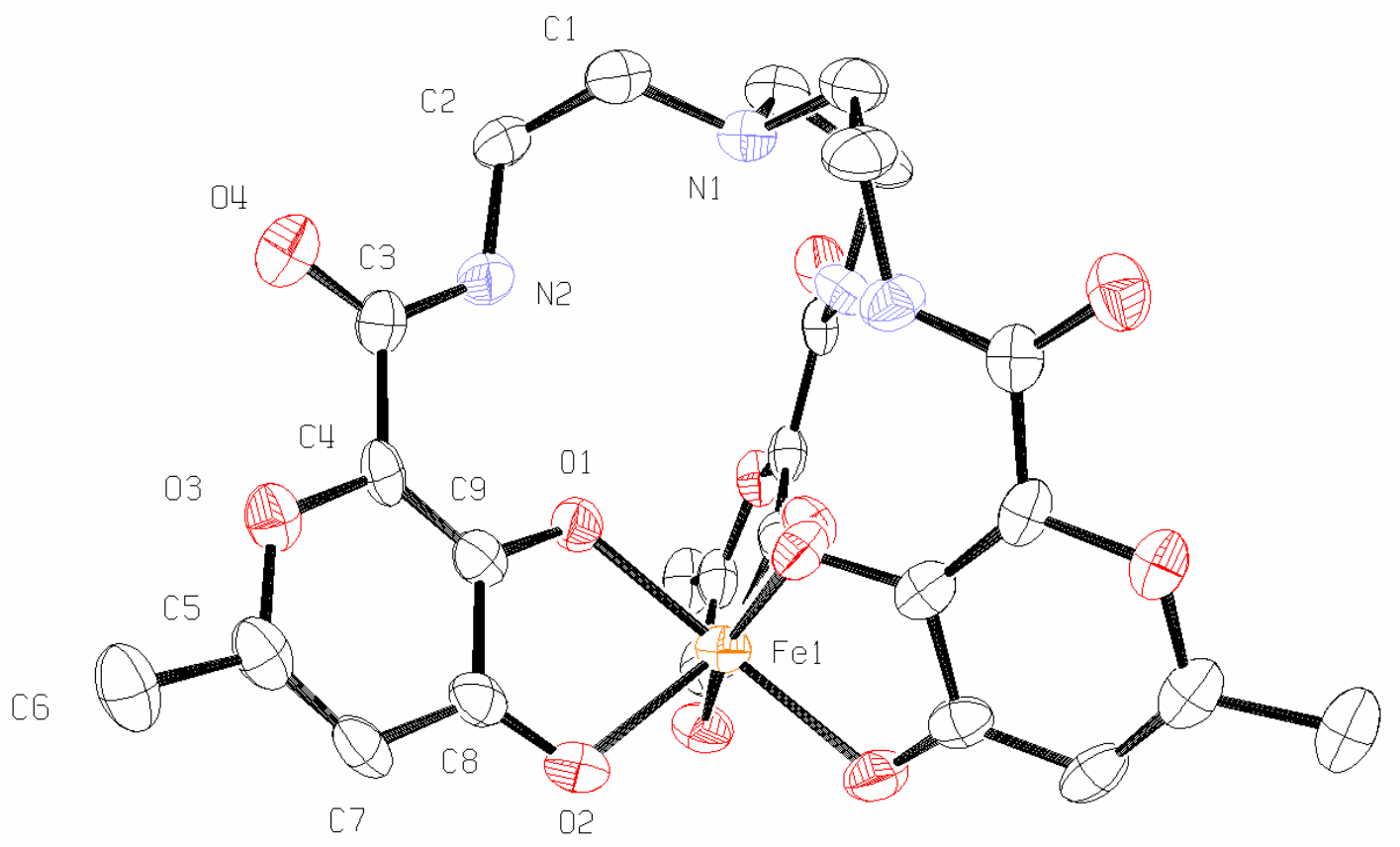

Figure S1. Structural diagram (50\% probability ellipsoids) of [Fe(TREN-Me-MAM)] showing the anticipated ligand structure, metal coordination, and internal hydrogen bonding (bonds not explicitly shown) typical of these tripodal complexes. Hydrogen bonds exist between the amide nitrogen protons and deprotonated hydroxyl oxygen atoms (e.g. between $\mathrm{N} 2$ and O1). Hydrogen atoms have been omitted for clarity. 

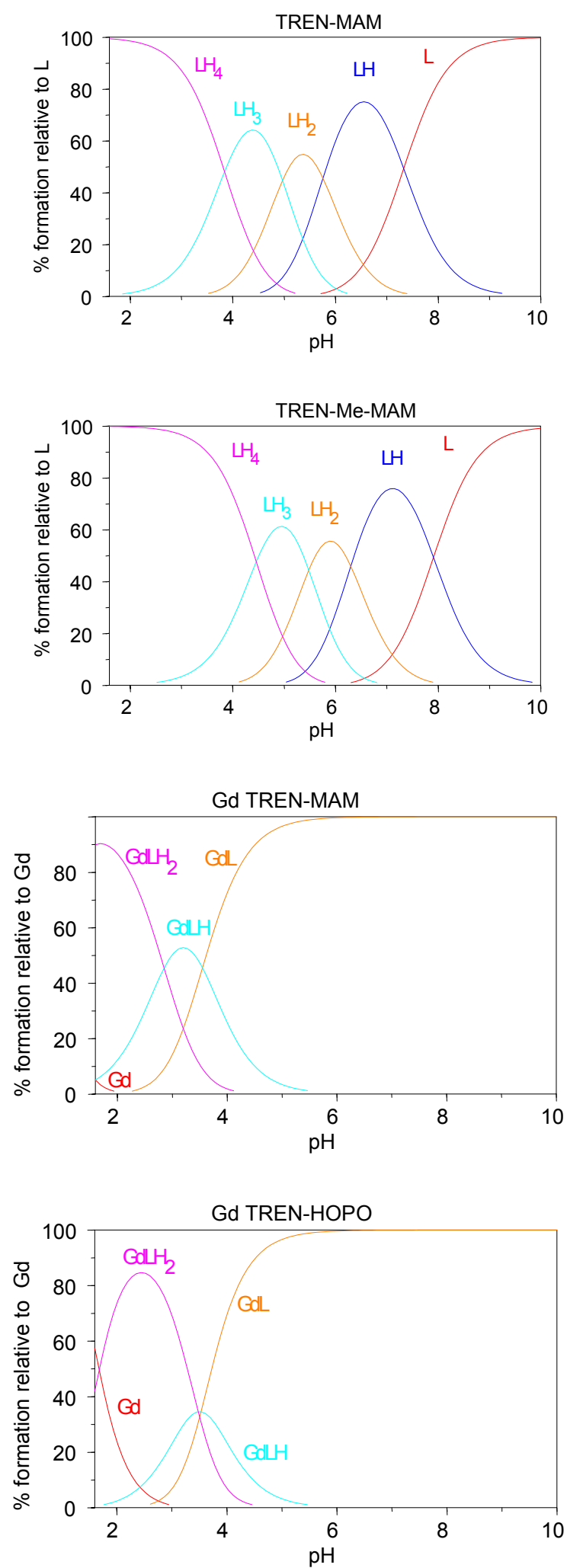
Figure S2. Comparison of the species distribution for (from top to bottom): TRENMAM, TREN-Me-MAM, [Gd(TRENMAM)], and Gd(TREN-Me-3,2-HOPO)]. 


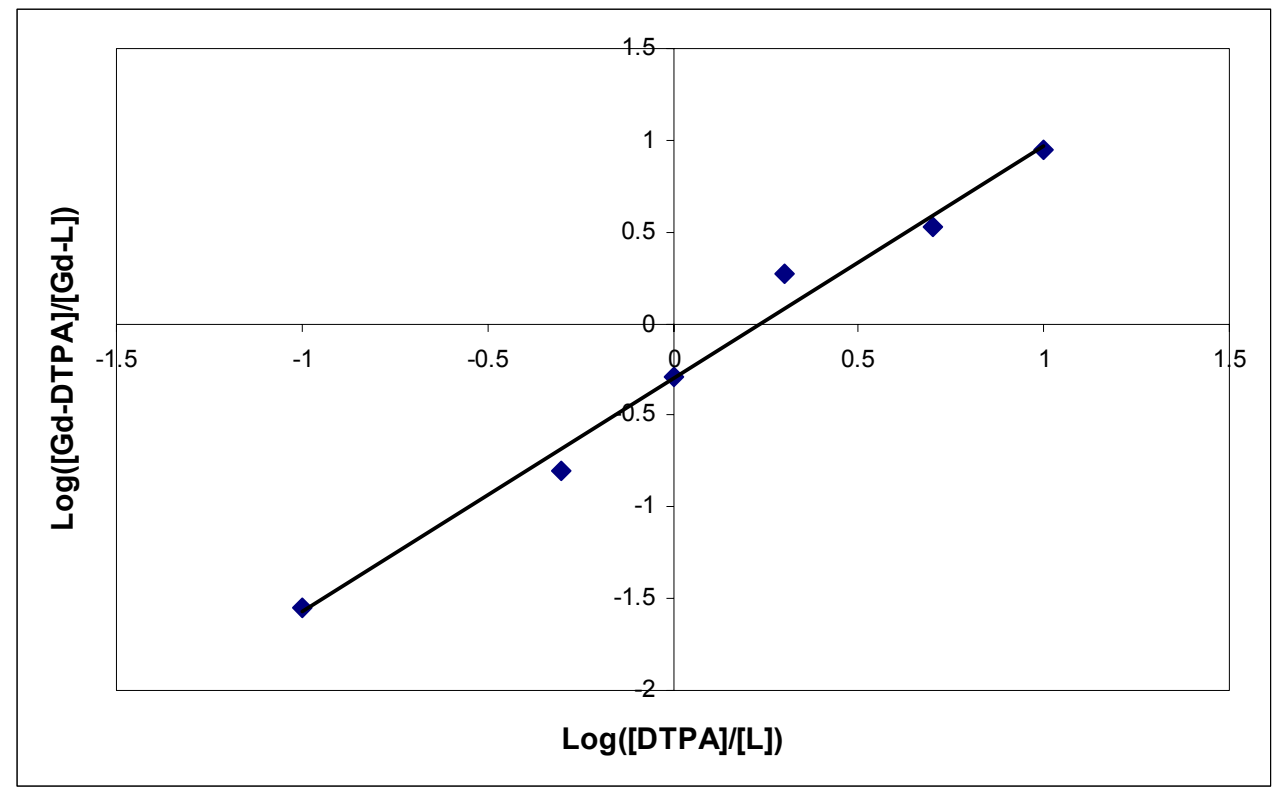

Figure S3. Representative plot of competition titration data. The $\mathrm{x}$-intercept indicates the difference in pGd between TRENMAM and DTPA. [TRENMAM] $=30.0 \mu \mathrm{M}$; [Gd] $=30.0 \mu \mathrm{M} ;[\mathrm{DTPA}]=3.00 \mu \mathrm{M}-300 \mu \mathrm{M} ; \mathrm{pH}=7.4 ; I=0.1 \mathrm{M} \mathrm{KCl}$. 


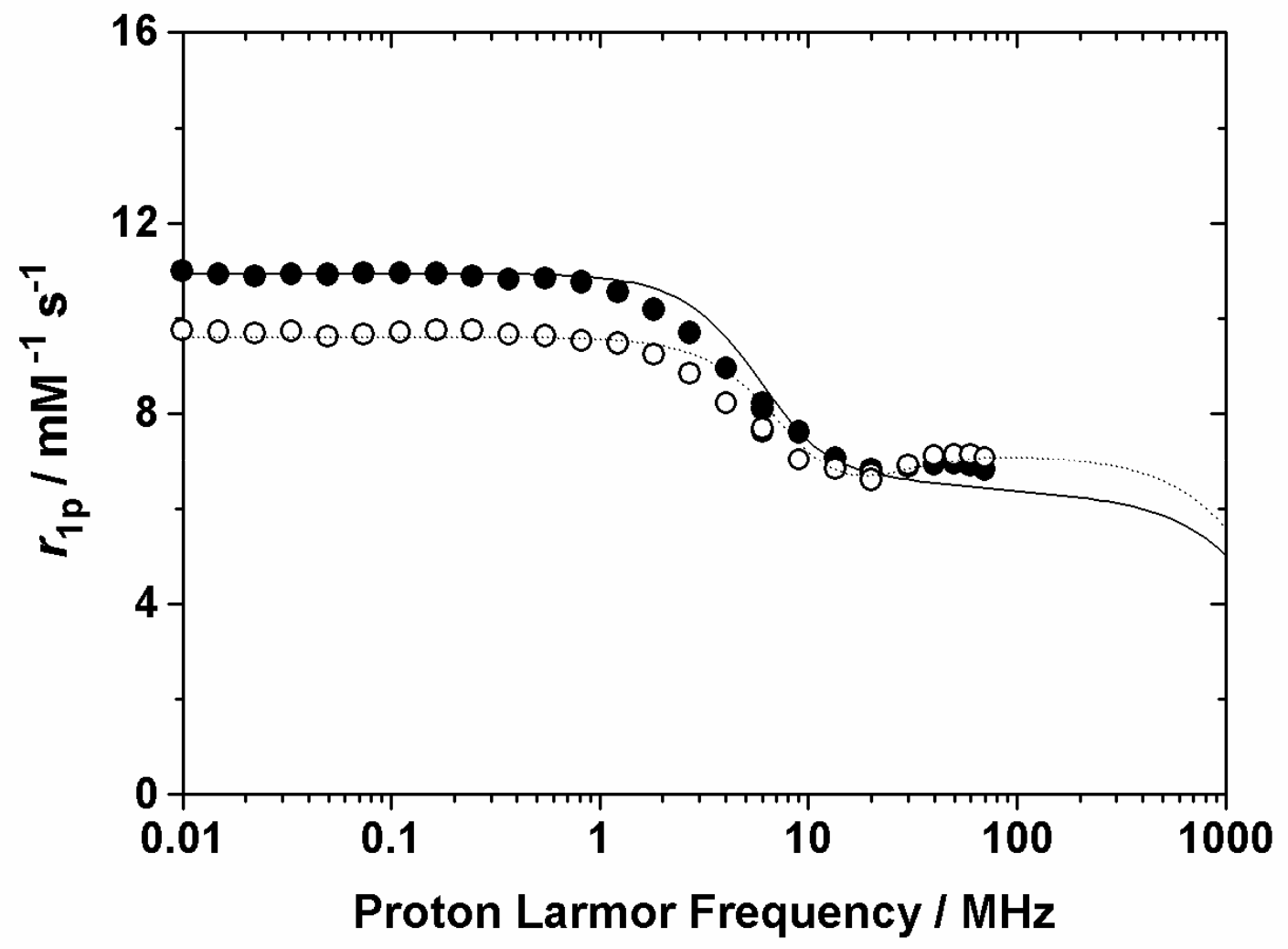

Figure S4. $1 / \mathrm{T}_{1}$ NMRD profiles of $\left[\mathrm{Gd}(\mathrm{TRENMAM})\left(\mathrm{H}_{2} \mathrm{O}\right)_{2}\right](\bullet)$ and $[\mathrm{Gd}(\mathrm{TREN}-\mathrm{Me}-$ $\left.\mathrm{MAM})\left(\mathrm{H}_{2} \mathrm{O}\right)_{2}\right](0)$, at $310 \mathrm{~K}$ and $\mathrm{pH}$ 7.2. 


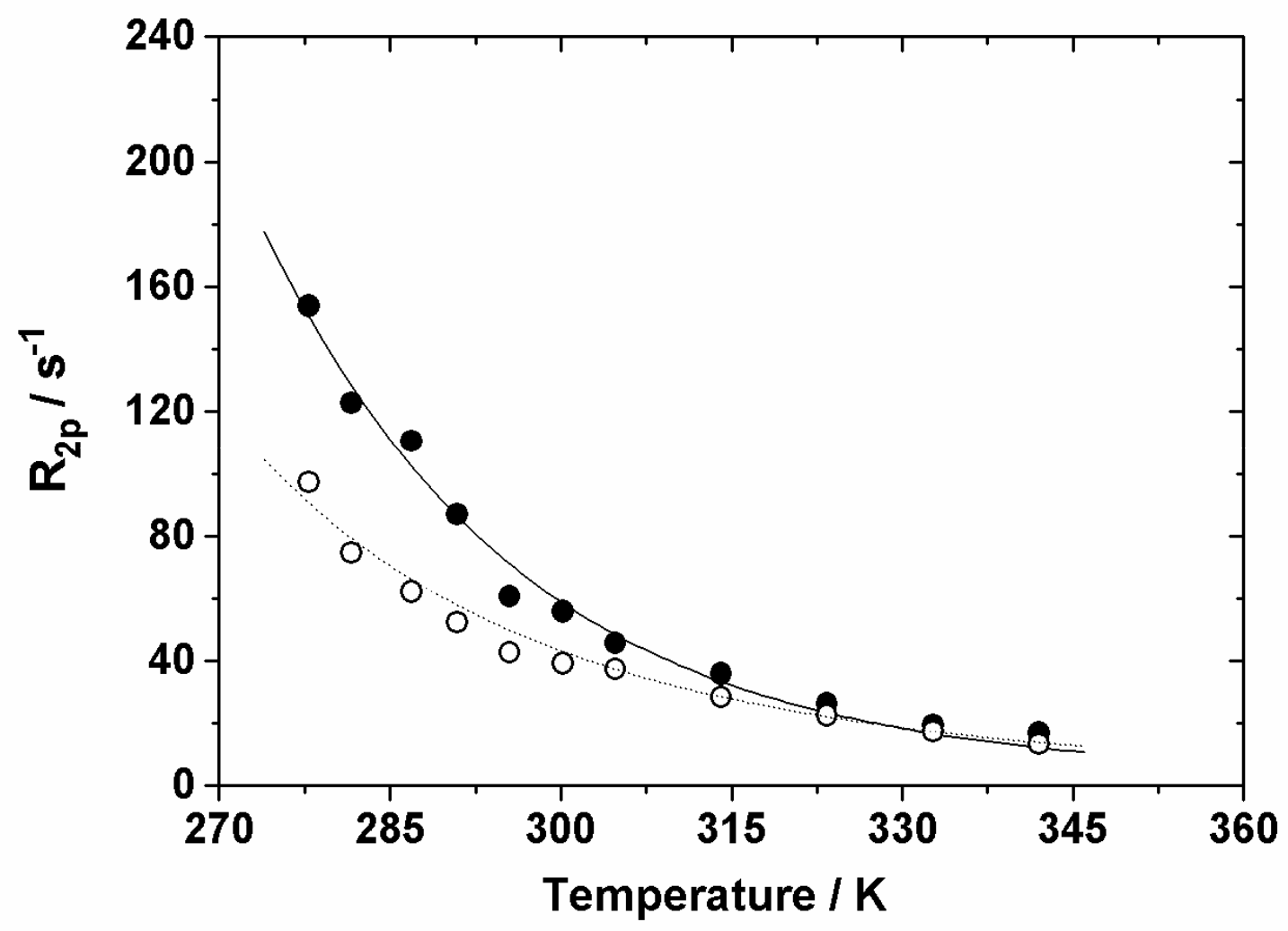

Figure S5. Temperature dependence of the paramagnetic contribution to the water ${ }^{17} \mathrm{O}$ NMR transverse relaxation rate $\left(R_{2 \mathrm{p}}\right)$ for $\left[\mathrm{Gd}(\operatorname{TRENMAM})\left(\mathrm{H}_{2} \mathrm{O}\right)_{2}\right](\bullet, 0.019 \mathrm{M})$ and $\left[\mathrm{Gd}(\mathrm{TREN}-\mathrm{Me}-\mathrm{MAM})\left(\mathrm{H}_{2} \mathrm{O}\right)_{2}\right](\circ, 0.013 \mathrm{M})$ at $2.12 \mathrm{~T}$ and $\mathrm{pH}$ 7.2. 